\title{
Extrapolation in the reading comprehension process in engineering students
}

\author{
July Rivera-Zamudio (Corresponsal author) ${ }^{1}$, Luis Alberto Núñez Lira ${ }^{2}$, Isabel Menacho Vargas ${ }^{3}$, Selene \\ Lorena Mercado Vinces ${ }^{4}$, Yolvi Ocaña-Fernández ${ }^{5}$
}

Universidad Nacional Mayor de San Marcos, Perú jriveraz@unmsm.edu.pe https://orcid.org/0000-0003-1528-4360

Universidad Nacional Mayor de San Marcos, Perú https://orcid.org/0000-0003-3542-9117

Universidad César Vallejo, Perú https://orcid.org/0000-0001-6246-4618

Universidad César Vallejo, Perú https://orcid.org/0000-0002-0206-4329

Universidad Nacional Mayor de San Marcos, Perú https://orcid.org/0000-0002-2566-6875

Article History: Received: 11 January 2021; Accepted: 27 February 2021; Published online: 5 April 2021

\begin{abstract}
The purpose of this research was to analyze the processes that allow students to develop reading comprehension through extrapolation. A mixed methodology was used, where through the descriptive correlational analysis between the study variables and the qualitative one that allowed describing and explaining the pedagogical processes carried out. Regarding the quantitative method, a purposive sample of 220 students from the engineering area of a public university in Lima, Peru, whose ages ranged from 16 to 20 years old, of both genders, was used. For the qualitative analysis, eight students were randomly selected. The results showed that the dimensions referring to reading comprehension had an average value of 53\% and the correlational analysis indicated a positive and regular average relationship between reading comprehension and extrapolation (Spearman's rho $=.394$ ). It was concluded that the use of extrapolation for the development of reading comprehension has been positive, reaching significant levels.
\end{abstract}

Key words: Extrapolation, critical thinking, reading, literacy method.

\section{Introduction}

The most notable difficulties for academic and intellectual development is undoubtedly the comprehension of what has been read. Students who are admitted each new academic year, particularly those in the area of applied sciences such as engineering, often present difficulties in the field of reading, due to not having developed specific skills such as understanding, inferring, extrapolating, among others, resulting in clear evidence of the reading deficit in these students. Such competencies should have been developed since basic education and remain there during the whole academic development, through the different disciplines and disciplinary areas and not necessarily from the area of communication since they are considered as a transversal and permanent practice. However, these deficiencies have been tried to be alleviated by the body in charge, through the implementation of more teaching hours in the specific area or by creating subjects at the higher level, whose results do not reach the expectations for which they were created. Likewise, there are soft skills that have not been developed either, such as motivation, the desire to excel, responsibility, among others, which makes many students reluctant to read. This is simply because the taste for reading has not been awakened, where undoubtedly, there are other factors that make it possible for them to stay away.

It is also necessary to establish that the interpretation of texts implies that these activities carried out by students are not necessarily correct, since errors are recurrent due to the conception and posture referred to their context and approach, together with the lack of skills and abilities for reading comprehension where rational and formal thinking has not been adequately developed or has not been stimulated.

In addition, it is frequent that students make literal or iconic readings whose interpretation is very limited, altering the meaning of the message or text read. Other difficulties, in this aspect, are oriented to the didactic processes whose objective is to implement systems of extrapolation in the comprehension of texts that allow their integration in the learning management processes. Such processes require teachers with skills that allow them to advice or guide in the comprehension of various types of texts at the most advanced levels, generating knowledge with autonomy and creativity, which is fundamental for the academic development of university studies.

Knowing how to read texts adequately implies strengthening the integral formation of university students, leading them to the development of cognitive, communicative and social competences that allow sustainable 
development and critical thinking, having a creative oral expression from the applications they can make through knowledge. Several researches carried out on text comprehension have not developed the subject of extrapolation, from a didactic vision, which allows to enhance the interpretation and systematization of information through the comprehension or production of texts, where university students present great difficulties, which facilitate them to acquire new knowledge and in turn the construction of the same; as for example the deficiency of information processing, which allows a construction and production of knowledge, deficient study skills, lack of learning goals and objectives, deficient vocabulary among others. Faced with these difficulties, it is proposed to develop text comprehension through extrapolation, which seeks the prediction or trend of a fact or phenomenon, based on a set of previous data. It could also be defined as a prospective with the creation of tendency or alternative scenarios. This leads us, according to Delors, to learning to know, learning to do, learning to live together, learning to be, in assuming as knowledge, knowing how to do and knowing how to be.

Along with the development of communicative competences in a transversal way, the development of soft skills such as creativity, social and cultural understanding, communication and effective collaboration, should be expressed through visual organizers and be submitted, in most cases, to a co-evaluation where the student will share the holistic learning of the investigated fact.

In this context, the following question is formulated: How is extrapolation carried out in the process of reading comprehension in students of General Studies in the area of engineering at a public university in Lima? The research is theoretically justified because it analyzes the relevant theories on reading comprehension and especially the didactic gaps found in the research problem, at the moment of carrying out the production of texts by university students. Methodologically it is justifiable because the research is carried out in an integral, holistic way, which allows the understanding of the fact in depth. It is epistemologically justified because it seeks to unravel the basis of the variable in context to be studied, from its history, the sciences of education, its philosophical and epistemological principles. From this perspective, the objective was established to analyze how extrapolation is carried out in the process of understanding texts in the aforementioned students.

\section{Methods and analysis}

According to several investigations, didactic processes aimed at text comprehension and production has not yet been implemented in educational institutions [1]. Therefore, at the level of university studies, it is urgent to develop higher levels of communication, due to the situations of reflection and constructive analysis [2]. In this regard, the comprehension of engineering texts in Chilean universities had several difficulties in developing text production, especially in the categories of textualization and revision [3]. Similar studies indicated the relevance of effective communication, whose strategies used were empirical methodologies in a sociocultural context; concluding that text comprehension is oriented more to linguistic knowledge and not properly to the development of communicative competences [4]. Research focused on developing learning strategies for the comprehension of scientific texts developed creative thinking and sensitivity for reading in order to build scientific thinking [5]. On the other hand, it is worth mentioning that innovative methodologies (interpretive/argumentative) enhanced text comprehension, which allowed students to express thoughts, feelings and interests in written form [6].

The development of communicative competences goes through the criteria of knowing, as well as developing skills and attitudes with the purpose of achieving the established goals in order to form and evaluate communicative competences through literary education and media literacy (audiovisual), thought as a fundamental element in the professional development of students [7]. These studies lead to infer that text comprehension is not only referred to the development of different competences, abilities and skills, but that they are linked to a specific content and to cognitive and meta-cognitive development, where the processes must be differentiated by the uniqueness of individuals to develop learning, where the importance of including extrapolation in the process of text comprehension in order to improve the individual's communicative abilities lies in this aspect. According to the above, the student should be able to reflect on a fact or phenomenon, create new learning and knowledge, and propose solutions to problems [8].

Communication, nowadays, comprises phenomenological, semiotic, informative and critical perspectives, which is understood as a systemic model. Therefore, the receiver of the messages emits responses with new messages according to the communicational objectives and in the context in which the question is asked by the sender. 
Hence, the importance that explains the urgency of developing skills and abilities of text comprehension, beyond the simple and common decoding of symbols [9]. These skills should be developed from the initial and primary level so that the student can interact between him and the author of the book and, later, can relate to his context or reality [10].

Reading comprehension and the communication process is dynamic, where the actors are active subjects, whose relationship is verbal or nonverbal, where interrelationships between people are deepened. Therefore, the purpose of teaching communication is to develop communicative competences that allow the individual to be able to understand in an original and creative way [11]. On the other hand, when individuals do not understand or comprehend the premises or statements, they usually generate difficulties in the development of the processes that allow the socialization of information between individuals, hindering or hindering human relationships [12]. The importance of curriculum integration allows the development of fundamental competencies, problem solving, complex thinking among others, seeking in the student the reflection and analysis in an autonomous way. It should always be kept in mind that text comprehension is an interdisciplinary activity in learning management; however, text comprehension is performed through algorithmic procedures, using strategies for interaction with texts from reading, without having taken into account or considered the processes of communicative extrapolation [1].

We must keep in mind that reading is a fundamental tool of the mind, which allows the person to interact with the text, recognizing the thought of the person who writes. To this end, the person's actions must be organized and orderly, using various tools of thought, managing to understand the various forms of language and to value what has been read. Complementarily, it can be established that it is a dialogic relationship between the reader and the text, which allows expanding the reader's mental schemes, with the ability to construct and reconstruct the text. Reading is the fundamental mechanism of the person to receive information, share experiences that transcend the cognitive by developing feelings and emotions; in addition to becoming a means of creation and recreation where three fundamental components reader/text/context are related [13, 14].

On the other hand, text comprehension is the process of elaboration of meanings by the reader that allows learning and that associates with their previous knowledge by interacting with the reading, assimilating the relevant ideas of the reading and correlating it with what has already been acquired or learned [15]. Reading is the conscious activity that allows people to obtain information from texts and hypertexts, allowing them to develop their education [16]. The reading process allows the individual to achieve learning, develop linguistic codes and higher level cognitive skills [17]. On the other hand, reading allows the development of interpretation and comprehension skills involving all the elements involved in the reading process [18].

There are three levels or types of reading: literal, transcendent and comprehensive. The literal level is oriented to the information retrieval process that allows readers to locate what they want to learn. The transcendent level is related to the valuation of reading, such as its application and prospective. At the comprehensive level, the reader assumes the positioning of what he/she reads, of the contents under a holistic view, analyzing the various correlations of the written network that allows reflection and the development of the ability to hypothesize [19]. On the other hand, it is worth mentioning that comprehension is linked to the type of reading, the reader's objectives, among others; and that, therefore, they generate the following types of reading: silent, done for the pleasure of reading (extensive), for obtaining information (intensive), fast (obtaining some information), involuntary (news), comprehensive (the whole document) which in turn can be of reflection, detailed and analytical, and selective (focused on a certain section of a text) [17]. According to another perspective, there are two types: selective and critical. The first refers to the recognition of the reader's intended objectives and expectations. The second allows an evaluation of the reading argument, which is strongly linked to the reader's previous knowledge of the subject matter [16].

Among the main processes of reading comprehension, six basic stages are proposed: identification of the graphic pattern that allows extracting data, access to the various meanings of the text, correlating connections of the syntax of the text, semantic interpretation that allows elaborating a construct or concept, inference that allows the reader to assume the author's positions, and reconstruction of the meanings of what has been read [19].

However, it is also necessary to consider that when reading, a set of operations of a mental nature is performed, such as perception that allows an analysis of the text read, information processing that allows finding 
conceptual findings, processing the lexicon and syntax, establishing the relationship of the spelling where the reader extracts the words and integrates it into his mental schemes to start the reasoning on the topic in question. Therefore, extrapolation is a process of comprehension and production of texts where readers have individual attitudes with decisions regarding what they read, i.e. the interdisciplinary text is used, allowing the exchange of information related to different points of view, improving their learning and self-regulating it, where communicative-socio-cultural competences are favored, integrating them and facilitating interaction in different contexts [1].

The treatment of extrapolation processes implies in-depth knowledge of the texts, whose attitude and decision making is linked to this process, together with the use of hypertexts whose regulation of learning processes will allow favoring communicative-cognitive learning and the adequate use of rhetoric, understanding meanings and developing knowledge [20]. Developing these competences implies contributing to the integral formation of the individual, allowing cognitive and emotional development, as long as it is related to the use of adequate didactic strategies that allow such a process. Therefore, it is necessary to promote formal thinking and cognitive development with the use of developmental methodologies [21]. Based on the above, the establishment of pedagogical strategies to carry out extrapolation processes in text comprehension implies that teachers should be drivers of learning management through developed approaches, adequately planning the processes, with challenging learning situations and empowering the student with tools that make it possible to satisfactorily face the world of knowledge from a creative perspective [22].

For the execution of the aforementioned processes, several principles are established, ranging from the structuring of the contents, their organization, methodology and pedagogical objectives. These principles are categories established in pedagogy, whose application corresponds to the teaching-learning process, constituting a starting point that generates pedagogical laws [23]. This represents models that respond to certain contexts, whose aims and goals structure thinking, feeling and acting, in addition to the integration of the various educational processes whose character is formative [24]. Therefore, the method is the element of the process that responds to how to develop the process, how to teach, how to learn, how to teach and how to learn. It represents the system of actions of teachers and students, as ways and modes of organizing interrelated activity, aimed at achieving the objectives [25].

To achieve the objectives, it is essential to follow the procedures that imply the feasibility of applying the various didactic methods, associated and contextualized to the reality of the individual, generating a sense of learning and where the teacher becomes a mentor [26]. Therefore, it is essential that the teacher performs the following activities or didactic processes such as extrapolation actions (using cognitive strategies and developing the ability to produce new concepts), designing tasks relating content and objectives (allowing intertextual and interdisciplinary development), linking the various contents for the adjustment of didactic activities in the production of texts, running the sessions from communicative situations of sociocultural character, allowing extrapolation, promoting comprehension and textual production with the use of logical operations; guiding various studies, enabling decoding and argumentation; permanent evaluation of the work done by students [1].

Regarding text comprehension, reading is fundamental for learning, where teaching is the axis of educational processes at all levels and whose implementation (since 1993) has not generated the expected results, according to national and international evaluations. As in the rest of Latin American countries, teaching didactics is oriented to orality and not to the interpretation of facts or phenomena whose evaluation does not reflect the purposes of text comprehension [27]. Therefore, text comprehension learning should develop individuals with reading skills who can build mental models from reading [28]. The reading/text association allows the development of reading learning levels: decoding, text-base, and situational modeling [29]. This relationship requires strategies for text comprehension that must be understood from the metacognitive level, which includes monitoring and self-disquisition, and reading operations, understood as memory, paraphrasing and elaboration [28]. In this framework, text comprehension and production are complex activities in which thinking and communication processes are immersed. Therefore, the first level of reading is decoding, in an accurate way, allowing, a posteriori, high-level processes [30].

The fact that written communication is given through signs that belong to a linguistic code should not be neglected. However, it should be kept in mind that reading is nothing more than interpreting, where comprehension is the key to the process of learning through reading. Thus, different people will have a different 
understanding of the same text, due to the reader's experience. Therefore, decoding and comprehension are two simultaneous processes. Likewise, the process of learning to read and write involves two joint and simultaneous processes, and how it is taught is important [31].

The measurement of reading skills, used in this research, is based on the use of the Evaluation of Reading Competence test (Ecomplec) [32], which will allow weighting the reading levels of the different texts (narrativeexpository-discontinuous), since it is based on the theoretical congruence of the 'Construction and Integration' model [29]. For this purpose, the following was designed as a strategy: To teach the student regarding the 'Compare/Contrast' structure based on the reading processes [28] as shown in Table 1.

Table 1. Reading processes.

Phases Processes

Phase 1 The teacher presents the objectives of the learning session with the purpose of getting used to the compare/contrast structure, where the definition is explained by explaining its definition.

Phase 2

It is explained that the different texts present a certain structure where the key-words for the comprehension of the message are identified.

$\checkmark$ The teacher performs the reading aloud promoting debate and discussion of the section of the text:

$\checkmark$ Introduction and analysis of the vocabulary used is performed.

$\checkmark$ Reading/analysis.

Phase $3 \checkmark$ Silent reading by paragraph, identifying and analyzing sentences establishing similarities and differences.

$\checkmark$ Elaboration of visual organizers of the paragraph supported by a matrix based on questions reflecting the type of structure.

$\checkmark$ What aspects does it deal with, which ones coincide, which ones differ in the paragraphs?

$\checkmark$ Then the teacher guides the development of the summary based on the questions generated.

Fhase 4

Explanation of the importance of the use of graphic organizers/summaries for the organization of information from the different readings.

Fhase 5 The benefit of using the learned strategies that facilitate text comprehension is reviewed.

The existence of various models for the realization of reading comprehension processes should be taken into account. One of these models was the 'Direct Model' [33] shown in Figure 1, which relates the knowledge of the person reading, his or her reading strategy and the subject of the text, which, together with the correct reading skills, are transformed into influential capacities or correlations for text comprehension.

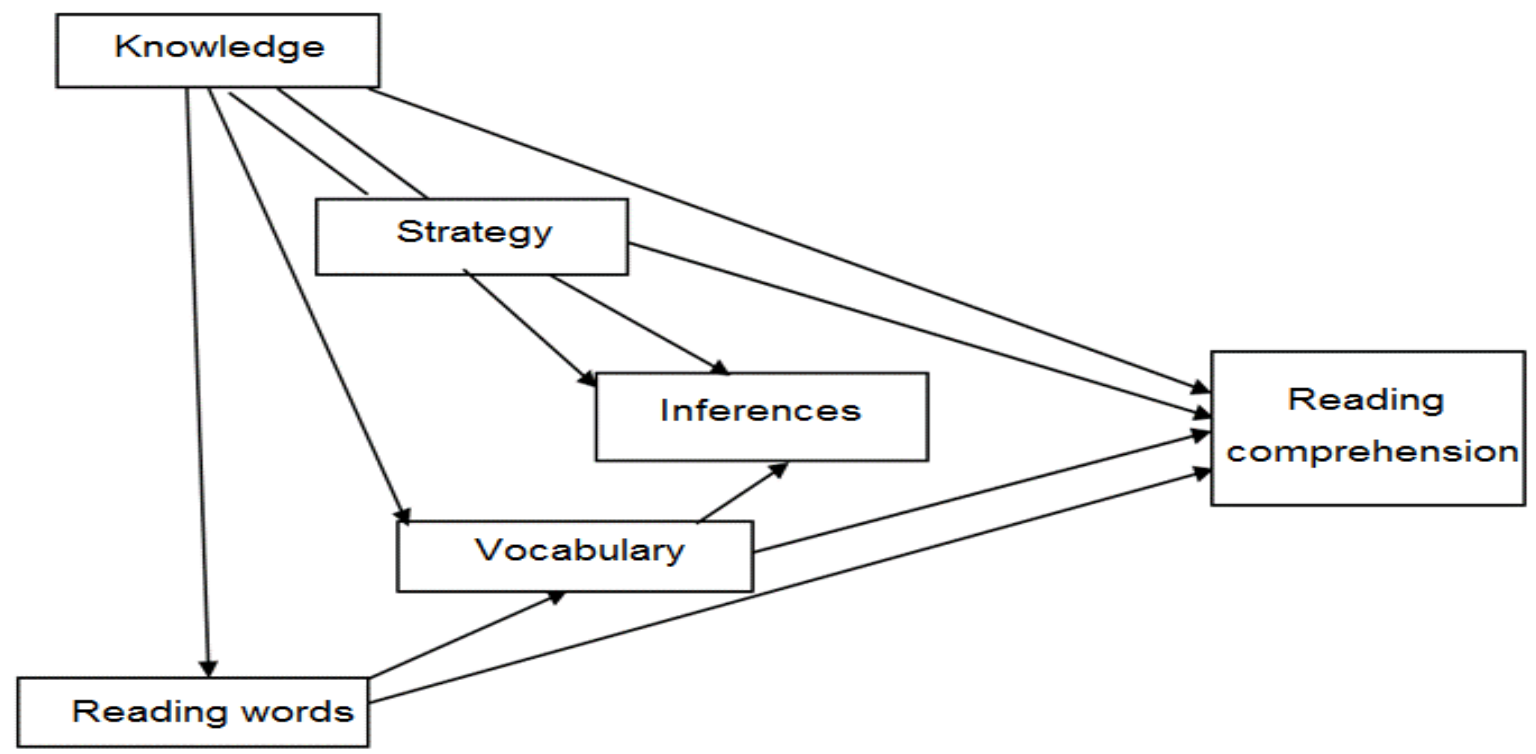


Figure 1. Direct model

It is also worth mentioning the existence of another model called 'Interactive' [17] shown in Figure 2; which establishes that reading comprehension is the result of the correlation of what is read and thematic knowledge and that, through contrastation, a new precise and detailed concept is established, marking the differences with other models where it shows that reading is not done in a linear way, but that mental processes are carried out in parallel.

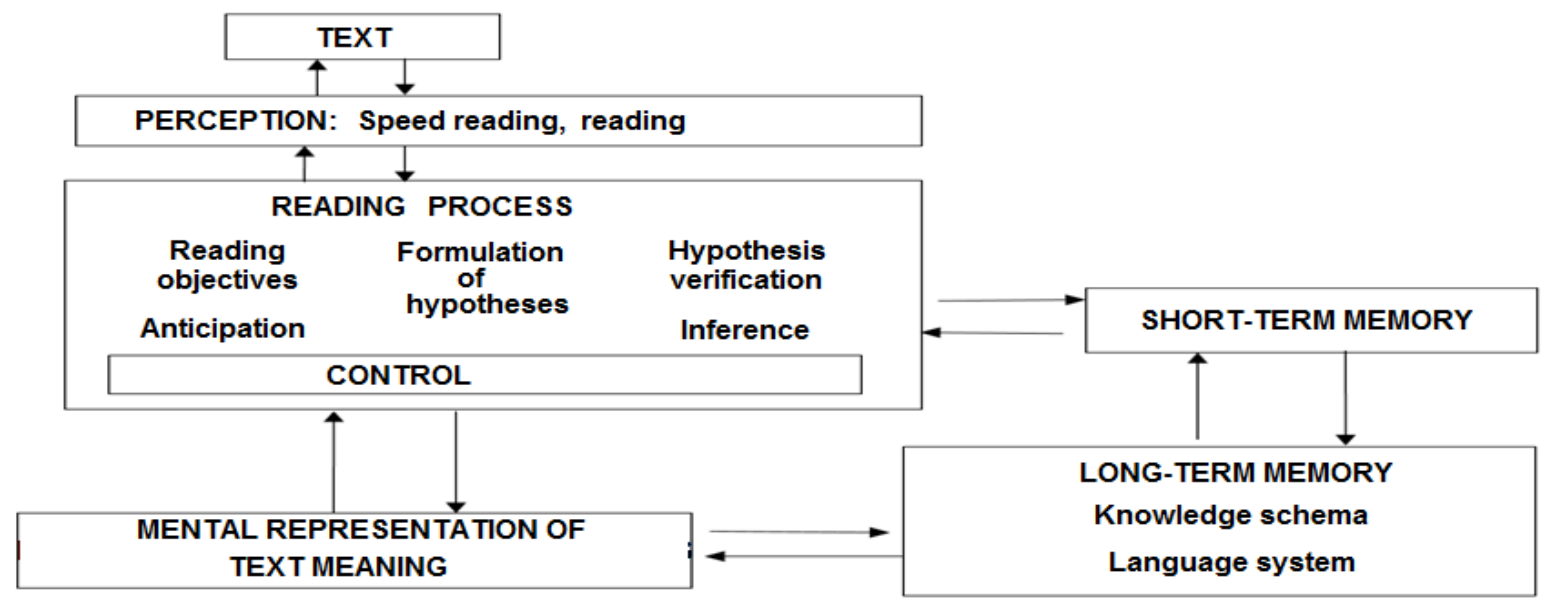

Figure 2. Interactive model

A third model, shown in Figure 3, establishes that information processing is bottom-up, allowing the reader to notice the various lower levels of reading such as figures and words, to reach the upper level of the document as sentences and the text itself. This requires oral actions, interpreting meanings and linking them for global comprehension. Likewise, the descending process is where the document to be read is analyzed, focusing on the semantics and syntax of the text $[34,35]$.

\begin{tabular}{|c|c|}
\hline MEDIUM / SUPPORT & $\begin{array}{l}\text { - Text print } \\
\text { - Electronic text }\end{array}$ \\
\hline $\begin{array}{c}\text { CONTEXT } \\
\text { (Only texts electronic) }\end{array}$ & $\begin{array}{l}\text { Environment of the author. The reader is } \\
\text { receiver and cannot change the information) } \\
\text { - Environment messaging. The reader can } \\
\text { modify the content, post blogs, chats...) }\end{array}$ \\
\hline TEXT FORMAT & $\begin{array}{l}\text { Continuous (trials, novels reviews, letters, } \\
\text { articles...) } \\
\text { - Discontinuous (graph, charts, forms, ads, } \\
\text { maps, diagram...) }\end{array}$ \\
\hline TYPE TEXT & $\begin{array}{ll}\text { - } & \text { Descriptive } \\
\text { - } & \text { Narrative } \\
\text { - } & \text { Exhibition } \\
\text { - } & \text { Argumentative } \\
\text { - Instructional } \\
\text { - } \\
\end{array}$ \\
\hline
\end{tabular}

Figure 3. Type of texts (OECD)

The dimensions that were considered to be evaluated in the present work on reading comprehension were: (i) 'Intelligent reading comprehension' which allows understanding reading literally, developing inferences and creating propositional bases, i.e. the reader is able to grasp the meanings "literal or explicit, intentional or implicit and complementary". (ii) 'Critical reading comprehension' which is manifested when readers adopt a 
position accepting or rejecting the text, making opinions, judgments and evaluations about what they have read. (iii) 'Creative reading comprehension' where the reader has the ability to apply or extrapolate what has been read to other realities [36].

Due to the nature of the study, a mixed, transdisciplinary study was chosen, under the naturalistic-interpretative methodology, to understand human nature and its diverse political/ethical positions [37]; seeking to capture reality from the perspective of the subject under investigation, whose reality is constantly changing [38]. The qualitative paradigm was used, developing a hermeneutic research due to the flexibility of analysis developed in order to be able to explain the meaning given by the subjects to the phenomena [39].

In the present work, the case study (multi-case) in education was assumed, which is characterized by verbally representing a given educational situation, being the unit of analysis the students of the engineering area of a public university in Lima, Peru, whose representation is logical/coherent, from the perspective and context; since, being a phenomenon with diverse perspectives, it is opted for the existence of convergence using the triangulation of data [40]. The approach adopted is quantitative, descriptive because it seeks to measure the expected results after measuring the variable studied, in our case the extrapolation in text comprehension, after the application of a test [41].

\section{Results and discussion}

The dimensions that were considered to be evaluated in the present work on reading comprehension were: (i) 'Intelligent reading comprehension' which allows understanding reading literally, developing inferences and creating propositional bases, i.e. the reader is able to grasp the meanings "literal or explicit, intentional or implicit and complementary". (ii) 'Critical reading comprehension' which is manifested when readers adopt a position accepting or rejecting the text, making opinions, judgments and evaluations about what they have read. (iii) 'Creative reading comprehension' where the reader has the ability to apply or extrapolate what has been read to other realities [36].

Due to the nature of the study, a mixed, transdisciplinary study was chosen, under the naturalistic-interpretative methodology, to understand human nature and its diverse political/ethical positions [37]; seeking to capture reality from the perspective of the subject under investigation, whose reality is constantly changing [38]. The qualitative paradigm was used, developing a hermeneutic research due to the flexibility of analysis developed in order to be able to explain the meaning given by the subjects to the phenomena [39].

In the present work, the case study (multi-case) in education was assumed, which is characterized by verbally representing a given educational situation, being the unit of analysis the students of the engineering area of a public university in Lima, Peru, whose representation is logical/coherent, from the perspective and context; since, being a phenomenon with diverse perspectives, it is opted for the existence of convergence using the triangulation of data [40]. The approach adopted is quantitative, descriptive because it seeks to measure the expected results after measuring the variable studied, in our case the extrapolation in text comprehension, after the application of a test [41]. 


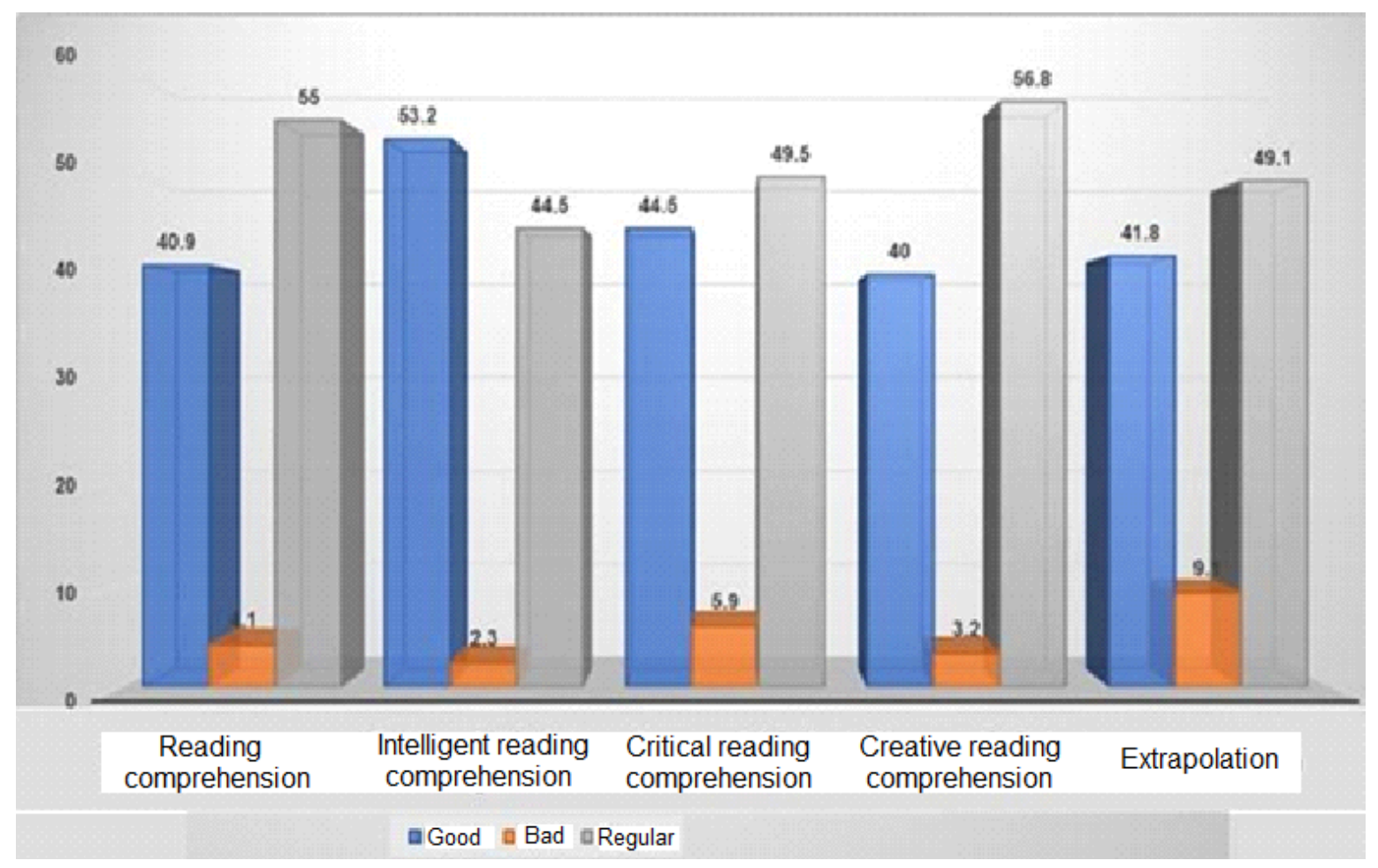

Figure 4. Descriptive levels of the variables under study.

Referring to the inferential statistics shown in Table 2, the correlations between the various aspects studied, according to the values obtained for Spearman's Rho coefficient, indicated that they had low levels $(\mathrm{p}<.01)$, so it can be established that other factors concurred that allowed the development of text comprehension in the aforementioned university students.

Table 2. Correlations of variables by Spearman's Rho.

\begin{tabular}{|c|c|c|c|}
\hline Variables/dimensions & $\begin{array}{l}\text { Coefficient } \\
\text { of correlation }\end{array}$ & $\begin{array}{c}\text { Significance } \\
\text { bilateral }\end{array}$ & $\mathrm{N}$ \\
\hline $\begin{array}{l}\text { Reading } \\
\text { comprehension+extrapolat } \\
\text { ion }\end{array}$ & $394 * *$ & ,000 & 220 \\
\hline $\begin{array}{l}\text { Intelligent reading } \\
\text { comprehension+extrapolat } \\
\text { ion }\end{array}$ & $245 * *$ &, 000 & 220 \\
\hline $\begin{array}{l}\text { Critical reading } \\
\text { comprehension+extrapolat } \\
\text { ion }\end{array}$ & $368 * *$ &, 000 & 220 \\
\hline $\begin{array}{l}\text { Creative reading } \\
\text { comprehension+extrapolat } \\
\text { ion }\end{array}$ & $346 * *$ &, 000 & 220 \\
\hline
\end{tabular}

With reference to the qualitative analysis, a selection was made of eight students of General Studies of the engineering area of a public university in Lima, whom we will call by their first names: Jaime, Jorge, Maritza, 
Diana, Maribel, Pedro, Marcos and Susana. All of them, under informed consent, provided relevant information to carry out the research from a qualitative perspective, where a participant methodology was applied in this process by the researcher.

With reference to the first objective on the incidence of extrapolation in the process of intelligent reading comprehension, the participating students demonstrated in the process that they reached the literal levels, where different texts were presented and all of them managed to obtain the expected results, even considering time management. In relation to making inferences, most of them were able to make them using extrapolation, although in the case of Jorge and Maribel they did it using a greater amount of time. Regarding proportional creation, most of them were able to establish some propositions and hypotheses based on the readings. In the learning sessions, it was possible to observe the use of the different types of reading used, as well as the didactic intention and the way in which the student should express the comprehension and expression of the text, which is systematized in Table 3.

Table 3. Types of readings for extrapolation.

\begin{tabular}{|c|c|c|c|}
\hline Type of text & Communicative intent & Linguistic features & Text forms \\
\hline Conversational & $\begin{array}{l}\text { Expresses emotions, } \\
\text { questions, orders, ... }\end{array}$ & $\begin{array}{l}\text { Exclamations, } \\
\text { interrogatives, } \\
\text { colloquialisms, ... }\end{array}$ & $\begin{array}{l}\text { Dialogues, letters, } \\
\text { conversations ... }\end{array}$ \\
\hline \multirow[t]{2}{*}{ Narrative } & \multirow[t]{2}{*}{ Tells stories, events } & $\begin{array}{l}\text { Abundant use of past } \\
\text { tense verbs }\end{array}$ & Novels, news, stories, \\
\hline & & Use of connectors & \\
\hline Descriptive & $\begin{array}{l}\text { Paints with words. } \\
\text { Highlight qualities }\end{array}$ & $\begin{array}{l}\text { Predominance of } \\
\text { adjectives. Verbs in } \\
\text { present and past tenses }\end{array}$ & $\begin{array}{l}\text { Brochures, guides, } \\
\text { catalogs, stories... }\end{array}$ \\
\hline Expositive & $\begin{array}{l}\text { To make understand, } \\
\text { to teach, ... }\end{array}$ & $\begin{array}{l}\text { Use of connectors and } \\
\text { exemplifications }\end{array}$ & $\begin{array}{l}\text { Manuals, definitions, } \\
\text { tests, ... }\end{array}$ \\
\hline Argumentativ & $\begin{array}{l}\text { Defend an idea and } \\
\text { convince. }\end{array}$ & $\begin{array}{l}\text { Use of connectors } \\
\text { Sintax complex and } \\
\text { ordered }\end{array}$ & $\begin{array}{l}\text { Speech, view articles, } \\
\text { publishers, ... }\end{array}$ \\
\hline Instructive & $\begin{array}{l}\text { To order, to inform, to } \\
\text { recommend }\end{array}$ & $\begin{array}{l}\text { Use of imperatives. } \\
\text { Exclamatives }\end{array}$ & Laws, rules, recipes, $\ldots$ \\
\hline Predictive & Anticipate, predict & $\begin{array}{l}\text { Use of futures and } \\
\text { conditionals }\end{array}$ & $\begin{array}{l}\text { Horoscopes, } \\
\text { prophecies, } \\
\text { meteorology }\end{array}$ \\
\hline Poetic / Literary & Expressing beauty & $\begin{array}{l}\text { Literary resources, } \\
\text { complex lexicon ... }\end{array}$ & $\begin{array}{l}\text { Literary genres, } \\
\text { advertising, ... }\end{array}$ \\
\hline
\end{tabular}

Thus, for each session different methodological strategies were used, depending on the type of text to be used, where descriptive texts that are textual sequences (narration, exposition, among others), its structure usually alludes to the object of the description, numbering of the parts and properties. These aspects led to a comparative analysis with other research, from which it was found that these processes have not been implemented, due to the weakness of the institutions to have teachers who present adequate levels to carry out extrapolation processes $[1,2]$; being necessary for universities to generate adequate levels of communication with teachers to reflect and undertake such extrapolation processes. 
Some studies reported great difficulties regarding the production of texts by students since, despite the use of empirical methodologies; they did not contribute to the development of communicative competences [3, 4]. Although other research reported that they managed to develop learning strategies using hermeneutics allowing the development of creativity, argumentation that allowed them to express thoughts in written form [5, $6]$.

It is important to establish a dialogic relationship between the reader and the text, expanding the reader's mental schemes, with the ability to construct and reconstruct the text. share experiences and become means of creation and recreation $[14,13]$. Thus, reading involves extracting information to use it pertinently in mental processes and building situational models of the text treated, and generating diverse representations granting meaning to the text, linking contents and conclusions [15]. Reading is an activity that allows people to obtain information from texts and hypertexts, allowing them to develop their education that allows them to develop interpretation and comprehension skills involving all the elements involved in the reading process [16, 17].

The qualitative and quantitative data obtained presented coincidences, to the extent that the adequate handling of extrapolation in $41.8 \%$ of the surveyed population is reflected in the monitoring and follow-up of the students selected for the qualitative research, where most of them were able to extrapolate and understand the texts that were made available to the students.

Regarding the second objective about how extrapolation affects the process of critical reading comprehension, the students demonstrated in the process that they achieved critical reading comprehension, that in the face of the diversity of texts they were able to obtain the expected results. To this end, the students gave their opinions, evaluated and assumed positions in relation to what they had read. Some of them with greater difficulty than others. The strategies employed by the teacher through the formation of work teams and the strengthening of both hard and soft skills, allowed establishing mechanisms of comprehension and criticality. In some cases (students) had difficulties in carrying out these processes, especially due to lack of digital competencies.

The development of communicative competencies requires knowledge, skills and attitudes to achieve the established goals, through media literacy (audiovisual). Thus, text comprehension allows the development of competencies, skills and abilities, linked not only to cognitive and meta-cognitive development, but also to extrapolation capabilities to understand texts in order to improve communicative skills [7]. Thus, the student reflects on something specific, new learning, knowledge and problem solving [8]. In addition to generating a multidisciplinary perspective, it contextualizes, where the message has holistic aspects, allowing understanding phenomenological, and semiotic, informational and critical perspectives, i.e., a systemic model. This shows us the need to develop skills and abilities of text comprehension, beyond the simple decoding of symbols [9].

Text comprehension is linked to the type of reading, the reader's objectives, among others, and therefore generates the following types of reading [17]. There are three levels or types of reading: literal/transcendent/comprehensive, the latter is where the reader assumes the positioning of what he/she reads [19]. Therefore, there is an urgent need to establish principles on how to elaborate the contents aimed at the teaching-learning process [23].

With reference to the third objective on extrapolation affects the process of creative reading comprehension, some students reached this level, where they made inferences and deductions, exemplified and extrapolated, where a good group reached this objective. For such an achievement to be given, an acceptable comprehension is required, with semantic mastery of verbs, nouns and adjectives that allow their knowledge development; that is, communication is a dynamic process, and where teaching-learning aims at developing communicative competences in an original and creative way [11]. When this does not occur, it hinders human relations and conflict resolution [12]. However, text comprehension is performed through algorithmic procedures [1], without taking into account the processes of communicative extrapolation. These processes should be developed from the earliest stages of learning (childhood), developing the ability to construct meanings with the various readings, learning to read and participate in society and personal enjoyment [42] and, fundamentally, to perform operations of a mental nature. In this framework, the maturity of the student will allow extrapolation in the comprehension and production of texts that allow exchanging information and improving their learning through communicativesocio-cultural competence, integrating them and being able to interact in different contexts [1]. This would imply 
that extrapolation deepens knowledge to make decisions and favor communicative learning and employ rhetoric by understanding meanings and developing knowledge [20, 21].

Text comprehension implies identifying the implicit patterns in the text for the extraction of information and that later will allow them to make the respective summaries and ultimately assume a position in relation to the reading. With this it is affirmed that, if the teacher establishes pedagogical strategies of extrapolation in his daily praxis, he will allow students to develop complex thinking, clearly designing the management of learning, creating situations or analyzing cases that mean a challenge and most importantly, providing the student with tools, not only technological but also mental, to achieve the proposed objectives.

A fundamental aspect that should be assumed is referred to the monitoring of the various didactic procedures and methods, associated and contextualized according to the reality of the student's context, where the teacher becomes a mentor [23]. Therefore, the activities planned should be focused on extrapolation actions, designing tasks that correlate texts, linking different contents to produce texts. These didactic situations should have a sociocultural character, allowing extrapolation and promoting the comprehension and production of texts beyond decoding, but rather an argumentation and constant evaluation of the work.

Understanding a text implies that people develop reading skills and this in turn, develop learning levels: decoding, text-base and situational modeling [28]. Therefore, the teacher is obliged to develop strategies aimed at developing text comprehension, from a metacognitive perspective, where the monitoring of reading operations is fully monitored until learning autonomy is achieved.

\section{Abstract}

The quantitative and qualitative analysis of extrapolation and reading comprehension in engineering students of a public university in Lima, has shown that both analyses are strongly associated, so that their joint implementation allowed the student to understand various texts, using extrapolation, whose results demonstrate the effectiveness of the methodology used. This also explains that reading is an act of communication, whose mental and cognitive processes intervene directly between the reader and the message, where he reproduces and constructs a meaning from his own perspective that will allow him to apply it to his daily life. Therefore, he will understand the explicit, directly expressing a message; implicitly, when he discovers the written message between the lines; and culturally, expressing the depth of the reading, which allows him to enrich his cultural legacy.

Likewise, extrapolation and intelligent reading comprehension have shown that both are strongly associated and that they allow the reader to obtain, process, evaluate and apply the information obtained from reading in an original and creative way. It is at this point where the reader decodes, textualizing the reading, who's reading processes are in the search for meanings -of the texts- that allow facilitating the processes of inferences, whose basis is centered on the meanings of the text. Also, extrapolation and critical reading comprehension have shown that both are strongly associated and allow the reader to reach levels of interpretation, using argumentation and assuming a position before the text, and this is associated with intelligent reading comprehension. The reader is able to distance himself from the text in order to criticize it, evaluate it, and position himself in the convenient aspects or by expertise.

Finally, extrapolation and creative reading comprehension have shown that both are strongly associated and allow the reader to reach deep levels of reading, where application, exemplification and extrapolation are the results of the reading comprehension process.

\section{References}

[1] Díaz-Berenguer S. La extrapolación desde una visión didáctica en el preuniversitario [tesis de doctorado] Cuba: Universidad de Oriente; 2017.

[2] Rivera-Zamudio JB, Alberca-Pintado NE. Estrategias didácticas y comprensión lectora en estudiantes universitarios. PSIQUEMAG, Revista Científica Digital de Psicología 2020; 9 (1): 118-130. doi:10.18050/psiquemag.v9i1.2498

[3] Vine-Jara. AE. Academic Writing: Perceptions of Students of Human Sciences and Engineering Sciences at a Chilean University. Ikala, Revista de Lenguaje y Cultura 2020; 25 (2): 475-471. doi:10.17533/10.17533

[4] Pérez-Vásquez, Y. La competencia comunicativa del docente en el ámbito escolar. Revista Transformación 2017; 13 (3): 394-405. 
[5] Duarte- Gandaria O, Sobrino-Pontigo E, Acosta-Gómez I. Interdisciplinary teaching-learning strategy for the understanding of scientific texts. Pedagogía y Sociedad 2019; 22 (54): 134-152.

[6] Esparza-Acosta LM. Las competencias lectoras y su incidencia en el desarrollo de la escritura de los estudiantes de básica superior de la unidad educativa 17 de Julio [ tesis de grado] Ecuador: Pontificia Universidad Católica del Ecuador; 2019.

[7] Reche-Urbano E, Martín-Fernández M, Vilches-Vilela MJ. La competencia literaria y comunicativa en la formación inicial del docente. Presentación de una experiencia. International Journal of Technology and Educational Innovation 2016; 2 (2): 138-144. doi: 10.20548/innoeduca.2016.v2i2.1977

[8] Benoit-Ríos C. Competencia comunicativa en una actividad curricular de lenguaje con estudiantes chilenos de Pedagogía. Revista Espacios 2018; 39 (46): 1-24.

[9] Silva-Trujillo M. El estudio de la comprensión lectora en Latinoamérica: necesidad de un enfoque en la comprensión. Revista Innovación Educativa 2014; 14 (64): 47-55.

[10] González-Hernández K, Arango-Rodríguez L, Blasco-Flanego N, Quintana-Arteaga K. Comprensión lectora. variables cognitivas y prácticas de lectura en escolares cubanos. Wímb lu. Revista Electrónica de Estudiantes de la Escuela de Psicología. Universidad de Costa Rica 2016; 11 (1): 39-57.

[11] Núñez K. Semantic domain and reading comprehension in students of the Faculty of Education at the Universidad Nacional Federico Villarreal. Lima-Peru. Consensus 2017; 22 (1).

[12] Mainegra-Fernández D, Miranda-Izquierdo J, \& Cué-Infante, J. Comprensión de textos escritos con el apoyo de conocimientos matemáticos en secundaria básica. Revista Electrónica Actualidades Investigativas en Educación 2018; 18 (1): 1-27. doi: 10.15517/aie.v18i1.31405.

[13] Solé I. Estrategias de lectura. Barcelona: Graó; 1994.

[14] Fumero F. Estrategias didácticas para la comprensión de textos. Una propuesta de investigación acción. Investigación y Postgrado 2009; 24 (1), 46-73.

[15] Jiménez E. La comprensión lectora. Andalucia: España; 2009.

[16] Argudín Y, Luna M. Desarrollo del pensamiento crítico. México: Plaza y Valdés Editores; 1999. Libro del profesor.

[17] Cassany D, Luna M, Sanz G. Enseñar Lengua. Barcelona: Graó; 2002.

[18] Instituto de Ciencias y Humanidades. Propedéutica de Razonamiento Verbal. Lima: Lumbreras Editores; 2012. Tomo I y II.

[19] Cáceres J. Comprensión lectora. Lima: Biblioteca Nacional del Perú; 2010.

[20] Berenger S. La extrapolación desde una visión didáctica en el preuniversitario [tesis de maestría] Santiago de Cuba: Universidad de Oriente; 2016.

[21] Castellanos D, Castellanos B, Llivina M, Silverio M, Reinoso V, García C. Aprender y enseñar en la escuela: una concepción desarrolladora. La Habana: Pueblo y Educación; 2002.

[22] Addine F. Didáctica teoría y práctica. La Habana: Pueblo y Educación; 2004.

[23] Zilberstein-Toruncha J, Silvestre-Oramas M. Reflexiones acerca de la necesidad de establecer principios didácticos para un proceso de enseñanza aprendizaje desarrollador. La Habana: Centro virtual de recursos, CREA; 2000.

[24] Roméu A. Metodología de la enseñanza del español. La Habana: Pueblo y Educación; 2011.

[25] Díaz M. Modelo didáctico del desarrollo e la originalidad en la producción de textos escritos en los escolares de sexto grado de la educación primaria [tesis de grado]. Santiago de Cuba: UCP "Frank País García”; 2012.

[26] Silvestre M, Zilberstein J. Hacia una Didáctica desarrolladora. La Habana: Pueblo y Educación; 2002.

[27] Madero I, Gómez L. El proceso de comprensión lectora en alumnos de tercero de secundaria. Revista Mexicana de Investigación Educativa 2013; 18 (56): 113-139.

[28] Vega. N, Bañales G, Reyna A, Pérez E. Enseñanza de estrategias para la comprensión de textos expositivos con alumnos de sexto grado de primaria. Revista Mexicana de Investigación Educativa 2014; 19 (63): 1047-1068.

[29] Kintsch L. Comprehension: A paradigm for cognition. Nueva York: Cambridge University Press; 1998.

[30] Golder C, Gaonac’h D. Leer y comprender. Psicología de la lectura. México: Siglo XXI Editores; 2002. 
[31] Paredes J. Decodificación y lectura. Revista Electrónica Actualidades Investigativas en Educación 2006; 6 (2). doi:10.15517/aie.v6i2.9215

[32] León J, Escudero I, Olmos R. Evaluación de la comprensión lectora. Madrid: Tea ediciones; 2012.

[33] Cromley JG, Azevedo R. Probar y perfeccionar el modelo de mediación directa e inferencial de comprensión lectora. Journal of Educational Psychology 2007; 99 (2): 311-325.

[34] Gough P. One second of reading. En Language by ear and by eye. Cambridge. Mass: MIT Press; 1972.

[35] Smith F. Comprensión de la lectura. análisis psicolingüístico de la lectura y su aprendizaje. México: Trillas; 1983.

[36] Roméu A. Aplicación del enfoque comunicativo: comprensión. análisis y construcción de textos. La Habana: Editorial Pueblo y Educación; 2005.

[37] Denzin N, Lincoln Y. The Sage Handbook of Qualitative Research. Londres: UK, Seagate; 2005.

[38] Gurdián-Fernandez A. El paradigma cualitativo en la investigación socio-educativa. San José, Costa Rica: PrintCenter; 2010.

[39] Izcara-Palacios SP. Manual de investigación cualitativa. México: Fontamara; 2014.

[40] Yin RK. Case study research: design and methods. London: Sage publications; 2003.

[41] Hernández R, Mendoza C. Metodología de la investigación. Las rutas cualitativa, cuantitativa y mixta. Mexico: McGrawHill; 2018.

[42] Ministerio de Educación Español. Estudio Internacional para el Progreso de la Comprensión Lectora. Madrid: Omagraf; 2009. 